\title{
SUUREN YLEISÖN SOITTORASIAT
}

\section{Radio Suomen, Radio Novan ja Radio Suomipopin soittolistat ja niiden rakenne}

Radiota on perinteisesti pidetty musiikin johtavana jakelukanavana. Vaikka internetin digitaalisten musiikkipalvelujen, kuten Spotifyn ja YouTuben, on arveltu kaventaneen radion merkitystä (Hagen 2015; Seemer ym. 2016), radion on nähty myös sopeutuneen ketterästi uuden teknologian vaatimuksiin hyödyntämällä digitaalisia alustoja ja sosiaalista mediaa (Bonini ym. 2014). Radiota kuunnellaan lähes yhtä paljon kuin vuosituhannen vaihteessa, mutta nyt se on saatavissa eri päätelaitteiden kautta (Finnpanel 2018). Myös levy-yhtiöille radiosoitoilla on artistien markkinoinnissa yhä suuri merkitys (Mattila 2017).

Vaikka radioasemat kilpailevat myös suosituimmista juontajista, ne luovat kuulijakuntansa ja ilmeensä nimenomaan soittolistoillaan, jotka ne räätälöivät vastaamaan kohdeyleisönsä toiveita (Ala-Fossi 2006a; Vilkko 2010). Esimerkiksi Sanoma-konserniin kuuluva Nelonen Media, joka hallitsee kuutta valtakunnallista radioasemaa, ei soita yhtään laulua testaamatta sitä ensin koeyleisöllä ja käyttää testaamiseen vuosittain yli miljoona euroa (Räisänen 2017). Vaikka myös Yleisradio käyttää tietokoneistettua musiikinhallintajärjestelmää, kaupallisista asemista poiketen se ei testaa musiikkiaan, vaan eri asemien eri puolilla Suomea kuultavat esitykset valitsee keskitetysti musiikkitoimituksen raati (Oinaala 2015). 
Radiomusiikista puhuttaessa kaupallisten asemien väitetään usein olevan toistensa kopiota ja soittavan entistä useammin entistä harvempia lauluja (AlaFossi 2006a). Myös maan kuunnelluinta radiokanavaa Radio Suomea on syytetty kapeisiin soittolistoihin siirtymisestä sekä kotimaisen musiikin, etenkin iskelmän, syrjimisestä (Iltalehti 18.10.2017; Tahvanainen 2017). Toisaalta tutkimus on osoittanut, että soittolistojen avulla asemat pyrkivät pikemminkin erottumaan toisistaan kuin muistuttamaan toisiaan (Chambers 2003; Vilkko 2010).

Suomessa on kolme suurta valtavirtayleisön radioasemaa, joiden yhteenlaskettu kuunteluosuus muodostaa lähes puolet kaikesta radion kuuntelusta. Artikkeli vertailee näiden kolmen aseman, Yle Radio Suomen, Radio Novan ja Radio Suomipopin, musiikkitarjontaa vuosina 2013 ja 2017 ja analysoi, miten niiden musiikkivalinnat poikkeavat toisistaan. Tarkastelu on saanut sytykkeen ajankohtaisesta radiokeskustelusta, mutta sen akateemiset lähtökohdat ovat yhtältä kilpailun vaikutuksia median sisältötarjontaan analysoivassa mediatalouden ja mediapolitiikan tutkimuksessa (Chambers 2003; Dimmick \& McDonald 2001; Napoli 1999; Vilkko 2010), toisaalta radiomusiikkia ja sen muutoksia koskevassa etnomusikologisessa tutkimuksessa (Kurkela 2009; Uimonen 2011). Markkinoiden luonnetta, kilpailuasemaa ja tuotedifferentiaatiota koskevaa teoriaa sovelletaan tässä radion musiikkiohjelmistolla käytävään kilpailuun. Sen mukaan kilpailu voi johtaa joko samankaltaistumiseen tai erilaistumiseen, riippuen kilpailutilanteesta. Radiomusiikin muutosta koskevasta tutkimuksesta puolestaan ammennamme soittolistojen ominaisuuksia ja erottumista kuvaavia mittareita.

Käytettyjen määrällisten mittarien avulla artikkeli osoittaa, että vaikka tutkitut asemat edustavat niin sanottua Adult Contemporary (AC) -formaattia, ne eivät musiikiltaan muistuta toisiaan, vaan pyrkivät soittolistojensa avulla nimenomaan erottumaan toisistaan, toisin sanoen ne käyttävät soittolistoja tuotedifferentiaation välineenä. Erottautumispyrkimys johtaa näiden kolmen aseman tapauksessa keskenään radikaalisti poikkeaviin tapoihin toteuttaa aseman musiikkiformaattia ja siihen nojaavaa soittolistaa. Tulosten pohjalta esitämme myös tutkittujen radioasemien musiikillisen profiilin. 


\section{Markkina-asema ja kilpailu radiotoimialalla}

Median monipuolisuus on keskeinen viestintäpolitiikan tavoite, ja laaja tutkimusperinne on kartoittanut eri media-aloilla vallitsevan kilpailun vaikutuksia ohjelmiston monipuolisuuteen (ks. esim. Litman 1992; Dimmick \& McDonald 2001; Napoli 1999). Vaikka toimialan rakenteen on havaittu vaikuttavan merkittävästi ohjelmatarjontaan, tulokset ovat osittain ristiriitaisia. Teollisen organisaation teoriaan nojaavan tutkimusperinteen mukaan kilpailijoiden ja tarjonnan lisääntyessä myös tarjottujen tuotteiden kirjo kasvaa, kun taas kriittinen taloustiede on esittänyt päinvastaisen teorian, jonka mukaan kilpailu lisää keskinäistä jäljittelyä ja tuotteiden samankaltaisuutta. Välittävän kannan ovat esittäneet viestinnäntutkijat van der Wurff ja van Cuilenburg (2001), joiden mukaan kilpailun ja tarjonnan monipuolisuuden välinen suhde ei olisikaan lineaarinen, vaan kilpailu edistää monipuolisuutta ainoastaan tiettyyn rajaan asti, kun taas liian kireäksi muuttuessaan kilpailu samankaltaistaisi kilpailijoiden ohjelmatarjontaa. Myös tässä tutkimuksessa lähdetään siitä, että maltillinen kilpailu monipuolistaa, kun taas kireä kilpailu voi samankaltaistaa ohjelmistoa.

Radiotoiminta on tyypillisesti oligopolistinen toimiala, jolla muutamat keskeiset toimijat tarjoavat yleisölle tiettyjä formaatteja noudattavia radioasemia ja jakavat markkinat keskenään (Sauri \& Picard 2017). Relevanttia kilpailua radiomarkkinoilla käyvät ensisijaisesti ne asemat, jotka palvelevat samaa maantieteellistä aluetta ja tavoittelevat samaa kohderyhmää soittamalla samankaltaista musiikkia. Terveesti kilpailevilla markkinoilla on yleensä asemia, jotka edustavat eri formaatteja, kuten Adult Contemporary (AC), Current Hit Radio (CHR), Classical ja Nostalgia. Formaatti on radioaseman strateginen työkalu, jonka avulla se profiloi lähetystoimintansa, lisää sen ennustettavuutta ja erottuu kilpailijoista. Etenkin kaupallisessa radiossa formaatti nojaa kapean soittolistan muodostamaan musiikkitarjontaan, joka suunnitellaan halutun kohderyhmän iän, sukupuolen ja joskus myös koulutuksen ja sosiaalisen aseman mukaan. (Barnes 1988; MacFarland 1997; Vilkko 2010.) Yhdysvalloissa formaatit määrittävät radiomarkkinoita niin vahvasti, että radiotarjonnan monipuolisuutta tyypillisesti mitataan eri formaatteja edustavien asemien saatavuudella ja määrällä (Berry \& Waldfogel 1999; Polinsky 2007; Rogers \& Woodbury 1996). 
Vaikka kilpailu Suomen radiomarkkinoilla on 2010-luvulla kiristynyt toimialan keskittymisen ja uusien toimilupien myötä (Hujanen \& Ala-Fossi 2017; Seemer ym. 2016), tässä tutkimuksessa lähdetään siitä oletuksesta, että radiotoimialan kilpailu on yhä maltillista. Kilpailua on hillinnyt se, että toimilupaviranomainen (aiemmin valtioneuvosto, vuodesta 2014 Viestintävirasto) on myöntänyt vain rajallisen määrän toimilupia asemille, jotka tavoittelevat samaa kohdeyleisöä ja soveltavat samaa formaattia. Kun esimerkiksi valtakunnallisia kaupallisia asemia oli vuonna 2017 kaikkiaan 13, niistä viittä voi pitää AC-asemina (Loop, Radio Nova, Radio Suomipop, Radio Iskelmä ja Radio Aalto). Yleisesti ajatellaan myös, että vahva julkinen palvelu, meillä Yleisradio, hillitsee kilpailua (Sauri \& Picard 2017).

Maltillisen kilpailun oloissa markkinoiden johtavat toimijat pyrkivät van der Wurffin ja van Cuilenburgin teorian mukaisesti parantamaan kilpailuasemaansa erilaistamalla tuotettaan, eli erottumalla muista laadullisesti tuotedifferentiaation keinoin (ks. myös Porter 1980). Radiotoimialalla tuotedifferentiaation keskeinen väline on musiikkiformaatti, jonka keinoin yritykset pyrkivät välttämään sen tilanteen, että ne olisivat toistensa duplikaatteja eli korvikkeita (Albarran 2002; Picard 1989). Useat tutkimukset ovat vahvistaneet populaarimusiikin ja erilaisten musiikkiformaattien merkityksen kaupallisten radioasemien menestystekijänä (Ahlkvist \& Fischer 2000; Rothenbuhler 1985). Musiikkiformaatista on tullut viimeistään 200o-luvulla myös suomalaista radiotoimialaa muovaava tekijä (Ala-Fossi 2005; Hellman \& Vilkko 2016; Kemppainen 2015; Uimonen 2011; Vilkko 2010). Formaatin avulla asema määrittää keskeisesti niin yleisönsä koostumuksen (ikä, sukupuoli) kuin koon (laaja vai suppea kohderyhmä). Musiikin roolia markkinoiden rakentumisessa korostaa myös se, että radion toimilupia koskevat päätökset ovat perustuneet siihen, "mikä on suunnitellun ohjelmiston pääasiallinen kohderyhmä, musiikkityyli tai muu pääasiallinen sisältö" (Valtioneuvosto 2011: 14).

Vaikka yhteinen formaatti viittaa siihen, että asemat soittavat samankaltaista ja osapuilleen samalle kohderyhmälle suunnattua musiikkia, ne voivat soveltaa samaa formaattia eri tavoin ja siten erottua toisistaan (Chambers 2003; Vilkko 2010). Tätä erilaistumista voidaan tutkia vain analysoimalla asemien soittamaa musiikkia. Esimerkiksi neljää klassisen musiikin radioasemaa Saksassa, Ranskassa ja Yhdysvalloissa vertaillut Krämer (2009) osoitti, kuinka julkisen palvelun 
asemat soittivat myös musiikillisesta kaanonista poikkeavia teoksia, kun taas kaupalliset verrokkikanavat nojasivat tunnetuimpien säveltäjien tunnetuimpiin teoksiin. Vastaavasti YleX:n, Radio Energyn ja Kiss Fm / The Voicen soittolistoja Suomessa vertailleet Hellman ja Vilkko (2016) havaitsivat hittiasemien soittaman musiikin olevan teostasolla hyvinkin erilaista, koska asemat hakivat formaatin puitteissa hieman toisistaan poikkeavia kuuntelijaryhmiä.

Yhdysvaltalaisia radioasemia analysoinut Barnes (1988) on ryhmitellyt ACasemat (1) täyden palvelun asemiin, (2) vanhoja hittejä soittaviin asemiin, (3) kevyttä pehmeää musiikkia soittaviin asemiin, (4) kapeisiin valtavirtapopasemiin ja (5) vaihtoehtomusiikkia tarjoaviin asemiin. AC-asemien kohdalla on puhuttu myös esimerkiksi Soft AC-, Hot AC- ja Urban AC -asemista (Williams ym. 2002). Esimerkiksi Radio Nova tuotiin Suomen markkinoille juuri valtavirtapoppia soittavana Soft AC -asemana (Ala-Fossi 1999; Vilkko 2010).

Radiomusiikkia koskevasta runsaasta tutkimuksesta huolimatta tutkimuksen metodologia ei ole kovin vakiintunutta (vrt. Ala-Fossi 2008; Barnard 2000; Uimonen 2008). Etnomusikologit ovat tutkineet radioasemien musiikkiohjelmiston valintaprosessia haastattelemalla musiikista vastanneita henkilöitä tai analysoimalla musiikinhallintaan liittyviä dokumentteja, mihin on usein yhdistetty myös soitetun musiikin analyysi (Kontukoski 2012; Kurkela \& Uimonen 2007; Uimonen 2009 ja 2011). Radiomusiikin muutoksia on myös selitetty esimerkiksi sukupolvinäkökulmasta (Kontukoski 2012). Mediatutkijat puolestaan ovat tutkineet radion musiikkitarjonnan rakenteita ja selittäneet muutoksia alan kaupallistumisella tai sääntelyn purkamisella (Ala-Fossi 1999 ja 2005; Hellman \& Vilkko 2016; Kemppainen 2009; Vilkko 2010).

Varsin harvoissa tutkimuksissa soitettua musiikkia, radioasemien soittolistoja, on analysoitu määrällisesti. Ala-Fossi (2006b) vertaili kaikkiaan 38 toimiluvanvaraisen radioaseman sisältöjä ja monipuolisuutta, jota mitattiin musiikkityylien jakaumasta laskettavalla suhteellisen entropian indeksillä, osoittaen näiden pääasiassa kaupallisten asemien soittaman musiikin lajikirjoltaan varsin kapeaksi (ks. myös Ala-Fossi \& Haara 2010). Vilkko (2010) vertaili viiden valtakunnallisen radioaseman soittolistoja analysoimalla niiden toiston määrää, kotimaisuutta, musiikin ikää, musiikkityylejä ja moodeja sekä havaitsi niiden kesken merkittäviä eroja teostasolla, eli siinä, mitä musiikkiesityksiä soittolista sisältää. Osittain samoja muuttujia ja mittareita käyttivät Hellman ja Vilkko (2016) vertaillessaan 
kolmen hittiaseman soittolistoja. Uimonen (2011) analysoi suurten kaupunkien johtavien paikallisradioiden musiikillista muutosta 1980-luvun puolivälistä 200o-luvulle ja havaitsi eri musiikkilajien tarjonnan merkittävästi kaventuneen formaattiradioon siirtymisen myötä.

\section{Tutkimusasetelma, tutkimusaineisto ja mittarit}

Artikkelin tavoitteena on tutkia, miten samoilla markkinoilla toimivat radioasemat kilpailevat keskenään tuotedifferentiaation keinoin. Tutkimme, miten kolme suosittua radioasemaa, Yle Radio Suomi, Radio Nova ja Radio Suomipop, jotka edustavat samaa AC-musiikkiformaattia, erottuvat toisistaan soittolistojen tasolla. Soittolistalla tarkoitetaan tässä kunkin aseman viikon aikana soittamaa musiikkia, ei vain esimerkiksi voimasoitossa olevia esityksiä tai prime time -soittoja. Näin siksi, että pyrimme hahmottamaan kuulijoille tarjottavan musiikillisen kirjon koko laajuuden. Useita toistoja saavien esitysten merkitys tulee esiin analyysissa, koska osa tunnusluvuista lasketaan soittojen kokonaismäärästä. Radion parhaaksi kuunteluajaksi luetaan Suomessa yleensä kello 6-18, jolloin ohjelmiston oletetaan olevan vakiintuneimmillaan (Ala-Fossi 2006b; Vilkko 2010). Kommentoimme prime timen soittolistoja sikäli kuin ne näyttävät poikkeavan muina vuorokauden aikoina soitetusta musiikista.

Kaikki tutkitut asemat on suunnattu aikuisille tai nuorille aikuisille. Aiemman tutkimuksen perusteella kaupalliset Radio Nova ja Radio Suomipop soittavat varsin samankaltaista rockiskelmistä, suomirockista ja keskitien popista koostuvaa populaarimusiikkia (Ala-Fossi 2006b; Ala-Fossi \& Haara 2010). Yle Radio Suomen musiikkiprofiilia sen sijaan ei ole aiemmin empiirisesti tutkittu (vrt. kuitenkin Nevasalmi 2014). Näiden kolmen aseman valintaa tutkimuskohteeksi perustelee niiden asema markkinajohtajina. 2010-luvulla Yle Radio Suomen ja Radio Novan kuulijamäärät ovat hieman laskeneet, kun taas Radio Suomipop on kasvattanut yleisöään. Kansallisen radiotutkimuksen mukaan Radio Suomen suurimman yleisöryhmän muodostavat yli 55-vuotiaat, kun taas Radio Novan merkittävin kuulijakunta muodostuu 35-54-vuotiaista ja Radio Suomipopin 25-44-vuotiaista (Finnpanel 2017; Tilastokeskus 2018). (Taulukko 1.) 


\begin{tabular}{|c|c|c|c|c|c|c|}
\hline \multirow[b]{2}{*}{ Tunnusluku } & \multicolumn{2}{|c|}{ Yle Radio Suomi } & \multicolumn{2}{|c|}{ Radio Nova } & \multicolumn{2}{|c|}{ Radio Suomipop } \\
\hline & 2013 & 2017 & 2013 & 2017 & 2013 & 2017 \\
\hline Päivätavoittavuus (\%) & 26 & 23 & 11 & 11 & 10 & 12 \\
\hline Päivätavoittavuus ikäryhmässä 25-34 (\%) & 6 & 5 & 9 & 9 & 16 & 19 \\
\hline Päivätavoittavuus ikäryhmässä 35-44 (\%) & 12 & 10 & 15 & 14 & 18 & 21 \\
\hline Päivätavoittavuus ikäryhmässä 45-54 (\%) & 26 & 22 & 19 & 17 & 14 & 15 \\
\hline Päivätavoittavuus ikäryhmässä 55-64 (\%) & 46 & 40 & 12 & 14 & 5 & 7 \\
\hline Päivätavoittavuus ikäryhmässä 65- (\%) & 54 & 49 & 5 & 5 & 1 & 1 \\
\hline Viikkokuulijamäärä (tuhatta kuuntelijaa) & 1907 & 1727 & 1272 & 1250 & 1131 & 1224 \\
\hline Kuunteluosuus (\%) & 33 & 32 & 8 & 9 & 7 & 8 \\
\hline Omistaja & Yleisradio & Yleisradio & Bonnier & Bauer & Sanoma & Sanoma \\
\hline
\end{tabular}

Taulukko 1. Yle Radio Suomi, Radio Nova ja Radio Suomipop vertailussa

Omistajataustaltaan yhtiöt edustavat suomalaisen radiokentän kolmea suurinta toimijaa. Vuonna 1990 osana Yleisradion radiouudistusta käynnistetty Yle Radio Suomi on osa valtion omistamaa Yleisradio Oy:tä, jolla on viisi muutakin analogista valtakunnallista radiokanavaa ja jonka yhteenlaskettu osuus radion kuuntelusta vuonna 2017 oli 49 prosenttia. Vuonna 1997 perustettu Radio Nova oli Suomen ensimmäinen valtakunnallinen kaupallinen asema, jonka omisti pitkään ruotsalaiseen Bonnier-konserniin kuuluva mTv Oy. Syksyllä 2015 Nova siirtyi saksalaiselle Bauer Media Groupille, johon kuuluu asemia yli 20 maassa, Suomessa muun muassa Iskelmä ja Radio City. Bauerin osuus Suomen radionkuuntelusta on 22 prosenttia. Radio Suomipop puolestaan perustettiin 2001, jolloin sen omistajana toimi Metromedia International Group. Vuonna 2012 Metromedia Finlandin enemmistöomistus siirtyi Nelonen Medialle, joka on osa Sanoma Media Finlandia ja jonka muita radioasemia ovat HitMix, Loop, Radio Aalto ja Radio Rock. Nelonen Median osuus radion kuuntelusta on 18 prosenttia. (Hujanen \& Ala-Fossi 2017; Tilastokeskus 2018.)

Tarkastelumme aineisto kerättiin yhdeltä maaliskuun ja yhdeltä syyskuun viikolta (viikot 10 ja 36) vuosina 2013 ja 2017. Aineisto perustuu musiikkiraportteihin, jotka asemat olivat toimittaneet esittävien taiteilijoiden tekijänoikeusjärjestölle Gramexille. Aineisto oli Excel-taulukkomuodossa ja listasi asemien 
soittaman musiikin kultakin tutkimusviikolta. Radio Suomen musiikkitarjontaa edustamaan valittiin aseman Uudellamaalla kuultava versio, Yle Radio Suomi Helsinki (aiemmin Ylen Aikainen), joka sisältää paitsi valtakunnallisesti kaikilla aseman taajuuksilla myös vain alueellisesti kuultavan musiikin. Listaus sisälsi jokaisen soitetun esityksen (levyn) nimen, artistin, levy-yhtiön, levynumeron, julkaisumaan, julkaisuvuoden sekä soittokertojen määrän. Levy-yhtiöitä ja levyn julkaisuvuotta koskevia tietoja jouduttiin täydentämään manuaalisesti, missä yhteydessä selvitettiin myös kunkin esityksen omistava emoyhtiö. Analyysiyksikkönä oli yksittäinen esitys (levy), ja saman laulun eri versiot luokiteltiin eri esityksiksi. Koska vertailtavana oli kaksi ohjelmaviikkoa kummaltakin tutkimusvuodelta, vuositason tunnuslukujen laskennassa käytettiin kahden viikon keskiarvoja.

Teosto- tai Gramex-raportit tarjoavat tutkimuksellisesti luotettavan pohjan analysoida radioasemien soittolistoja (Hellman \& Vilkko 2016; Kontukoski 2012; Uimonen 2011). Kahden kokonaisen viikon mittainen otos kummankin tutkimusvuoden musiikkitarjonnasta on riittävän pitkä soittolistojen rakenteen analysoimiseksi, sillä kuten aiemmat tutkimukset ovat osoittaneet, soittolista toistaa itseään (Ala-Fossi 2006b; Hellman \& Vilkko 2016; Vilkko 2010). Kahdelta eri vuodelta koottu aineisto puolestaan mahdollistaa soittolistojen muutosten havainnoinnin. Vuosi 2013 valikoitui mukaan siksi, ettei Gramexin uudistettu tietokanta ulotu kauemmas taaksepäin.

Useissa aiemmissa tutkimuksissa yhtenä soitetun musiikin monipuolisuuden ulottuvuutena on käytetty musiikinlajia, genreä (ks. esim. Ala-Fossi 2006b; Kontukoski 2012; Uimonen 2011; Vilkko 2010). Nämä tutkimukset kuitenkin osoittavat, ettei genre välttämättä erottele samaa formaattia edustavia asemia toisistaan. Ensinnäkin esimerkiksi popmusiikki on niin lähetyskanavan imagoon sidottua, että "sen nimissä voidaan esittää hyvinkin erilaista ja erilaisille yleisöille suunnattua musiikkia" (Hellman \& Vilkko 2016: 81). Kuten Uimonen (2011: 209) huomauttaa, radioasemat itse "liudentavat genrerajoja ja muokkaavat niitä toimintakulttuuriinsa sopivaksi". Toiseksi itse musiikkityylien on havaittu olevan jatkuvassa muutoksessa, jonka seurauksena esimerkiksi iskelmän, popiskelmän, rockiskelmän ja suomirockin rajat ovat osin hämärtyneet (Jalkanen \& Kurkela 2003; Kostamovaara 2012). Niinpä tässä artikkelissa genreä ei käytetä muuttujana, koska "se on epäherkkä kuvaamaan soittolistan luonnetta" (Hellman \& Vilkko 
2016: 81). Toinen syy on tutkimusekonominen: yli kolmentuhannen eri esityksen luokittelu musiikkityyleihin olisi edellyttänyt niiden kuuntelua. Vertailemme asemien ohjelmistoa teostasolla keskittyen genreä yksiselitteisempiin muuttujiin: (1) musiikin toiston määrään, (2) musiikin kotimaisuuteen, (3) musiikin ikään ja (4) soitettujen esitysten levy-yhtiöihin.

Toiston osalta oletamme aiemman tutkimuksen perusteella, että julkisen palvelun velvoitteen nojalla Yleisradio soittaa enemmän eri esityksiä ja siten myös toistaa niitä vähemmän kuin mitä kaupalliset asemat tekevät (Ala-Fossi 2006a; Hellman \& Vilkko 2016; Vilkko 2010). Kaupallisen radion tehtävänä on tarjota "vain sitä, mitä kuuntelijat haluavat", kuten Nelonen Median musiikkipäällikkö Jorma Koivusipilä on kuvannut radioasemiensa musiikillista missiota (Räisänen 2017). Soittolistan laajuutta Yleisradiossa voi selittää myös se, että musiikin valitsee musiikkipäällikön johtama raati, joka rakentaa tasapainoista kokonaisuutta (Nevasalmi 2014; Oinaala 2015), kun taas kaupallisten asemien harjoittama auditoriotestaus pakottaa valikoiman kapeammaksi (Mattila 2017; Räisänen 2017). Aiemmissa tutkimuksissa (Ahlkvist \& Fisher 2000; Chambers 2003; Hellman \& Vilkko 2016; Hendy 2000; Vilkko 2010) musiikkiohjelmiston monipuolisuutta on tutkittu juuri analysoimalla soittolistojen laajuutta ja toistoa. Tässä niitä mitataan neljällä mittarilla: (1) soittolistalla olevien eri esitysten (levyjen) määrällä, (2) soittolistalla olevien artistien määrällä, (3) esitysten keskimääräinen soittokertojen määrällä ja (4) vain kerran soineiden esitysten osuudella.

Vaikka kotimaisella musiikilla on merkittävä asema tutkituilla radioasemilla, oletamme niiden eroavan toisistaan kotimaisuusasteeltaan. Kotimaisella musiikilla tarkoitamme tässä Suomessa julkaistuja esityksiä (levyjä), mukaan lukien siis niin käännösiskelmät kuin englanniksi lauletut esitykset. Koska Radio Suomipop soittaa jo toimilupansa perusteella yksinomaan kotimaista musiikkia, sen musiikkiohjelmiston kotimaisuusaste on väistämättä korkein. Myös Yle Radio Suomen kotimaisuusasteen oletamme korkeaksi, koska yleisradiolaki edellyttää yhtiön edistävän kotimaista kulttuuria ja koska asemaan kohdistuu myös yleisön ja musiikintekijöiden suunnasta paineita suosia kotimaista musiikkia. Jos oletuksemme asemien pyrkimyksestä erottua toisistaan pitää paikkansa, vähiten kotimaista musiikkia pitäisi löytyä Radio Novan soittolistalta. Aiemman tutkimuksen perusteella on myös oletettavaa, että kaupalliset asemat nojaavat kapeampaan kotimaiseen ohjelmistoon kuin Yleisradion asema (Hellman \& Vilk- 
ko 2016; Vilkko 2010). Soittolistan kotimaisuusastetta ja kotimaisen soittolistan laveutta mittaamme kolmella mittarilla: (1) kotimaisten esitysten osuudella soitetusta musiikista, (2) soitettujen kotimaisten artistien absoluuttisella määrällä ja (3) soitettujen kotimaisten eri esitysten absoluuttisella määrällä.

Musiikin iällä viittaamme soitettujen levyjen julkaisuajankohtaan. Uuden musiikin esittäminen on kilpailutilanteessa olevalle radioasemalle aina jonkinlainen riski, mikä paitsi ohjaa kaupallisia asemia testaamaan soittolistalleen nousevat esitykset myös suosii kuulijoille jo tuttuja levyjä uusimpien sijasta (Rothenbuhler 1985; Uimonen 2011). Toisaalta musiikkimakua koskevan sukupolviteorian mukaan pysyvät mieltymykset syntyvät noin viidentoista vuoden iässä (Kontukoski 2012), minkä vuoksi esimerkiksi suuria ikäluokkia viehättää 1960-luvun, nykyisiä kolmikymppisiä taas 200o-luvun musiikki. Koska Radio Suomipopin ydinyleisö on verrokkikanavia nuorempaa, oletamme uutuusmusiikin korostuvan sen tarjonnassa muita enemmän. Vastaavasti oletamme ydinkuulijakunnaltaan vanhimpana näyttäytyvän Yle Radio Suomen soittavan muita asemia enemmän vanhaa musiikkia. Toisaalta Radio Suomen lavea kuulijakunta johtaa oletettavasti siihen, että se soittaa eri aikoina julkaistua musiikkia monipuolisemmin kuin kaupalliset kilpailijansa.

Olemme luokitelleet musiikin tässä tutkimuksessa kuuteen sen ilmestymisvuotta kuvaavaan kategoriaan. Kun A-kategoriaan lasketaan tutkimusvuonna (joko 2013 tai 2017) julkaistut esitykset, B-kategoriaan luokittelimme tutkimusvuotta edeltävänä vuonna (joko 2012 tai 2016) julkaistut esitykset, C-kategoriaan muut 2000-luvun julkaisut, D-kategoriaan vuosina 1990-1999 julkaistut esitykset, E-kategoriaan vuosina 1980-1989 julkaistut esitykset ja F-kategoriaan ennen 1980-lukua julkaistut esitykset. Soitetun musiikin jakautumista aikakausiin mittaamme kolmella mittarilla: 1) kategoriaan A kuuluvien esitysten osuudella musiikkisisällöstä, (2) kategoriaan F kuuluvien esitysten osuudella musiikkisisällöstä ja (3) eri aikakausia edustavan musiikin jakauman monipuolisuudella. Viimeksi mainittua mitataan suhteellisen entropian indeksillä (Shannonin H), jonka minimiarvo on o (kaikki esitykset edustavat samaa kategoriaa) ja maksimi I (esitykset jakautuneet tasan eri kategorioiden kesken). Tunnuslukua voidaan tulkita niin, että o,oO-0,39 edustavat erittäin vähäistä monipuolisuutta, $0,40-0,64$ vähäistä, $0,65-0,79$ keskimääräistä, $0,80-0,89$ suurta ja $0,90-1,00$ erittäin suurta monipuolisuutta. (Hellman 2001; McDonald \& Dimmick 2003.) 
Radioasemien suhdetta levy-yhtiöihin on Suomessa tutkittu vähän, vaikka radiosoitoilla on havaittu olleen suuri äänitteiden myyntiä edistävä vaikutus (Negus 1992) ja meilläkin on arvioitu kaupallisten radioasemien suosivan nimenomaan suurimpien levy-yhtiöiden hittejä (Gronow \& Kaitajärvi-Tiekso 2017; Vilkko 2010). Levytetyn musiikin markkinoita hallitsevat suuret niin sanotut majors-yhtiöt, joita nykyisin on kolme, Sony, Universal ja Warner ("Big Three"), joiden valta-asema on ulottunut lukemattomien tytäryhtiöiden ja niiden hallinnassa olevien levymerkkien kautta kaikkialle maailmaan. Niiden rinnalla toimii tuhansittain itsenäisiä levy-yhtiöitä, joiden kokoluokka vaihtelee suuresti. (MIDiA 2017; Wickström 2013.) Tässä tutkimuksessa jälkimmäisiä yhtiöitä kutsutaan indie-yhtiöiksi. Suomen tilastoidusta musiikkimyynnistä vuonna 2016 peräti 92 prosenttia oli Sony Music Entertainment Finlandin, Universal Musicin tai Warner Music Finlandin tuotantoa (Gronow \& Kaitajärvi-Tiekso 2017: 259). Paitsi että ne hallitsevat uuden musiikin julkaisemista ja maahantuontia, niiden käsissä on myös lukuisten aiemmin itsenäisten levy-yhtiöiden tuotanto. Esimerkiksi Love Recordsin ja Poko Recordsin katalogit ovat nykyään Universal Music Finlandin hallussa. Oletamme Radio Suomella julkisen palvelun toimijana tuovan esiin myös itsenäisesti toimivia levy-yhtiöitä ja niiden tuottamaa musiikkia, niin kotimaista kuin ulkomaista, kun taas kaupallisten asemien odotamme suosivan suuryhtiöiden tuotantoa. Big Three -yhtiöiden osuutta analysoidaan tutkimuksessa Sonyn, Universalin ja Warnerin julkaisemien tai omistamien esitysten yhteenlasketulla osuudella kunkin aseman radiosoitoista. Osuutta mitataan erikseen koko musiikkiohjelmistosta ja soitetusta kotimaisesta musiikista.

Monia yllä esitellyistä mittareista on käytetty jo aiemmissa tutkimuksissa (Alhlkvist \& Fischer 2000; Chambers 2003; Hellman \& Vilkko 2016; Vilkko 2010), mutta tässä lisätään monipuolisuutta kuvaavaan mittaristoon kunkin esityksen toistojen keskiarvo sekä kuvataan soitetun musiikin kotimaisuutta kotimaisten esitysten absoluuttisella määrällä. Kokonaan uutta on tarkastella soitetun musiikin ikää matemaattisen monipuolisuusmittarin avulla, jota on tosin aiemmin sovellettu genreanalyysissa (Ala-Fossi 2006b). Majors-yhtiöiden markkinaosuudet ovat tärkeä mittari musiikkiteollisuuden tutkimuksessa (Dowd 2004), mutta tiedossamme ei ole, että radiomusiikin tutkimuksessa niiden osuutta olisi aiemmin analysoitu. 
Etnomusikologinen tutkimus käyttää harvoin määrällisiä menetelmiä. Tässä artikkelissa hyödynnämme mediatutkimuksen puolelta lainattuja mittareita osoittaaksemme soittolistojen moniulotteisuuden ja eri asemien musiikilliset profiilit. Määrällinen analyysi ei sulje pois mahdollisuutta analysoida radiossa soitettavaksi valittua musiikkia laadullisesti, esimerkiksi musiikkianalyysin tai etnografian keinoin. Ne eivät kuitenkaan kuulu tämän tutkimuksen lähestymistapaan.

\section{Radioasemien vertailu}

Musiikin määrä. - Tutkimusaineistoomme sisältyi kaikkiaan 22398 radiosoittoa. Vuonna 2017 tutkitut asemat soittivat (toistoineen) vuorokaudessa 220-340 musiikkiesitystä (kuvio 1). Musiikki ohjelmasisältönä näyttää korostuneen, koska kaikki asemat olivat lisänneet musiikin määrää vertailujakson aikana, Yle Radio Suomi jopa neljänneksellä, mikä johtuu muun muassa urheiluohjelmien siirrosta Yle Puheeseen. Yle Radio Suomi käyttää musiikkia kuitenkin edelleen selvästi verrokkiasemia vähemmän. Eniten musiikkiin nojaa tutkituista asemista Radio Suomipop.

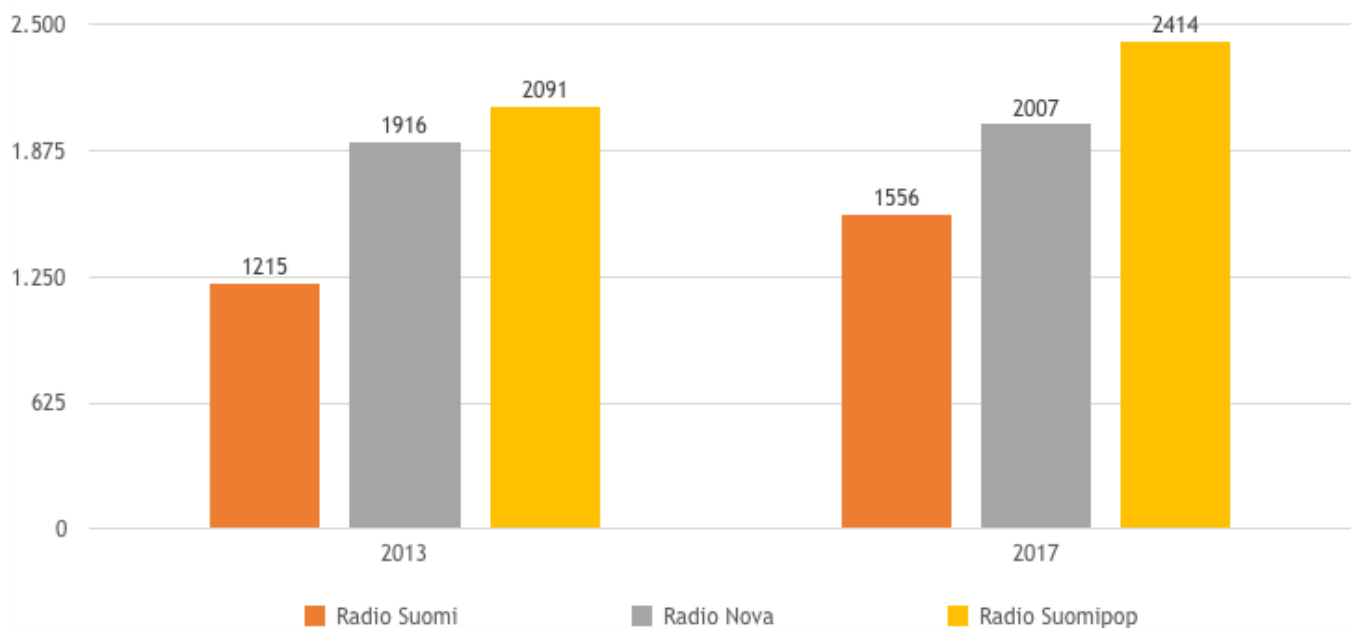

Kuvio 1. Musiikkiesitysten määrä toistoineen viikossa radioasemilla 2013 ja 2017 
Toisto. - Toiston määrä soittolistoilla kertoo musiikin monipuolisuudesta. Radioaseman musiikkiohjelmisto on sitä monipuolisempaa, mitä useampia esityksiä ja artisteja se tarjoaa, mitä vähemmän samoja esityksiä toistetaan ja mitä suurempi osa esityksistä kuullaan vain kerran viikon aikana (taulukko 2). Vuonna 2017 Yle Radio Suomi soitti lähes kaksi kertaa enemmän eri esityksiä kuin Nova ja yli neljä kertaa enemmän kuin Suomipop. Neljänneksen lisäys eri esitysten määrässä vuoteen 2013 verrattuna on Radio Suomen kohdalla merkittävä, samoin neljänneksen lasku Radio Suomipopin kohdalla. Vielä selvemmin asemat erottuvat toisistaan, kun niitä verrataan artistien lukumäärän perusteella. Vuonna 2017 Radio Suomessa pääsi viikon aikana ääneen kaksi kertaa enemmän artisteja kuin Novassa ja yhdeksän kertaa enemmän kuin Suomipopissa.

\begin{tabular}{llcccccc} 
& \multicolumn{3}{c}{ Yle Radio Suomi } & \multicolumn{2}{c}{ Radio Nova } & \multicolumn{2}{c}{ Radio Suomipop } \\
Toiston mittarit & $\mathbf{2 0 1 3}$ & $\mathbf{2 0 1 7}$ & $\mathbf{2 0 1 3}$ & $\mathbf{2 0 1 7}$ & $\mathbf{2 0 1 3}$ & $\mathbf{2 0 1 7}$ \\
Eri esitysten määrä / vko & 985 & 1244 & 653 & 673 & 359 & 266 \\
Artistien määrä / vko & 744 & 882 & 373 & 405 & 100 & 97 \\
Esitysten keskimääräinen soittomäärä / vko & 1,2 & 1,2 & 2,9 & 3,0 & 5,8 & 9,1 \\
Vain kerran viikossa soineiden esitysten osuus (\%) & 84,1 & 81,1 & 48,9 & 34,3 & 12,4 & 10,5
\end{tabular}

Taulukko 2. Toiston määrä soittolistoilla

Käsitystä Yle Radio Suomen vähäisestä toistosta vahvistaa se, että sen soittamat levyt soivat keskimäärin 1,2 kertaa viikossa, kun taas Radio Novalla soittokertoja kertyi keskimäärin 3,o ja Suomipopilla peräti 9,1. Asemista vain Suomipop oli lisännyt toistojen määrää merkittävästi vuodesta 2013. Radio Suomen soittamista esityksistä yli 8o prosenttia soi vain kerran viikossa, Radio Suomipopin esityksistä vain kymmenisen prosenttia. Radio Nova on asemista ainoa, joka on merkittävästi vähentänyt kerran soitettavien esitysten osuutta. Tulokset vahvistavat, että tutkitut asemat erottuvat selvästi toisistaan toiston ulottuvuudella: Radio Suomella toisto on selvästi vähäisintä, Radio Suomipopilla selvästi suurinta.

Kotimaisuus. - Mitä suuremman osan radioaseman soittamasta musiikista (toistoineen) kotimaiset esitykset saavat ja mitä useampia kotimaisia artisteja ja esityksiä asema soittolistalleen nostaa, sen kotimaisempaa sen tarjonta on (tau- 
lukko 3). Radio Suomipopin sadan prosentin kotimaisuusaste on sinänsä selkeä osoitus siitä, että radioasema voi rakentaa liiketoimintamallinsa Suomessa julkaistun musiikin varaan. Toisaalta Radio Novan vaatimaton ja vuodesta 2013 romahtanut kotimaisuusaste osoittaa, ettei suomalainen formaattiradio tarvitse menestyäkseen juurikaan kotimaista musiikkia. Yle Radio Suomen kasvanut kotimaisuusaste viittaa puolestaan siihen, että suomalaisuus korostuu aiempaa enemmän aseman julkisessa palvelussa. Asemien kotimaisuusaste noudattaa oletettua jakaumaa.

\begin{tabular}{lcccccc} 
& \multicolumn{3}{c}{ Yle Radio Suomi } & \multicolumn{2}{c}{ Radio Nova } & \multicolumn{2}{c}{ Radio Suomipop } \\
Kotimaisuuden mittarit & $\mathbf{2 0 1 3}$ & $\mathbf{2 0 1 7}$ & $\mathbf{2 0 1 3}$ & $\mathbf{2 0 1 7}$ & $\mathbf{2 0 1 3}$ & $\mathbf{2 0 1 7}$ \\
Kotimaisuusaste soitoista (\%) & 54,8 & 56,7 & 40,4 & $\mathbf{1 4 , 3}$ & 100,0 & 100,0 \\
Kotimaisten artistien määrä / vko & 354 & 399 & 85 & 64 & 99 & 97 \\
Kotimaisten eri esitysten määrä / vko & 528 & 692 & 181 & 112 & 359 & 266
\end{tabular}

Taulukko 3. Soittolistojen kotimaisuus

Analyysi osoittaa myös, että suurikin kotimaisuusaste voidaan saavuttaa toistamalla harvojen artistien harvoja suosikkilevyjä. Sekä kotimaisten artistien että esitysten määrässä Yle Radio Suomi erottuu kilpailijoistaan selvästi. Vuonna 2017 se tarjosi viikon aikana neljä kertaa enemmän kotimaisia esiintyjiä kuin Radio Suomipop ja kuusi kertaa enemmän kuin Radio Nova. Eri kotimaisia esityksiä Yle Radio Suomi sisällytti viikkotarjontaansa lähes kolme kertaa enemmän kuin Suomipop ja kuusi kertaa enemmän kuin Nova. Kun kaupalliset asemat olivat kaventaneet soittolistansa kotimaisten artistien ja esitysten valikoimaa, Radio Suomi oli tuntuvasti laventanut molempia, mikä vastaa hyvin paitsi oletustamme myös sen julkisen palvelun roolia.

Aikakaudet. - Koska eri kuuntelijasukupolvien odotetaan mieltyneen eri aikakausien populaarimusiikkiin, oletimme uusimman musiikin korostuvan Radio Suomipopin soittolistalla, kun taas Yle Radio Suomi soittaisi eri aikakausia edustavaa musiikkia muita monipuolisemmin. Analyysin perusteella kaikki tutkitut asemat olivat vähentäneet uusimman musiikin määrää ohjelmistossaan (taulukko 4). Vahvistusta sai kuitenkin myös oletuksemme, että Radio Suomipop soittaisi eniten uusinta ja Radio Suomi vanhinta musiikkia. Tutkimusvuonna (2013 
tai 2017) julkaistu musiikki muodosti ainakin neljänneksen Radio Suomipopin tarjonnasta, kun taas neljännes Radio Suomen soittolistasta muodostui ennen 1980-lukua julkaistusta musiikista. Verrattuna nuorille suunnattuihin hittiasemiin AC-asemien panostus uusimpaan musiikkiin on vähäistä (Hellman \& Vilkko 2016).

\begin{tabular}{llccrrr} 
& \multicolumn{3}{c}{ Yle Radio Suomi } & \multicolumn{2}{c}{ Radio Nova } & \multicolumn{2}{c}{ Radio Suomipop } \\
Musiikin aikakautta koskevat mittarit & $\mathbf{2 0 1 3}$ & $\mathbf{2 0 1 7}$ & $\mathbf{2 0 1 3}$ & $\mathbf{2 0 1 7}$ & $\mathbf{2 0 1 3}$ & $\mathbf{2 0 1 7}$ \\
Kategorian A osuus soitoista (\%) & 15,6 & 12,5 & 15,7 & 5,4 & 29,0 \\
Kategorian F osuus soitoista (\%) & 28,7 & 25,4 & 3,8 & 3,5 & 2,7 \\
Aikakausijakauman monipuolisuus (H) & 0,97 & 0,95 & 0,87 & 0,76 & 0,87
\end{tabular}

Taulukko 4. Soittolistan musiikin jakautuminen aikakausiin

Myös aikakausijakauman monipuolisuutta kuvaava mittari antaa tukea oletuksillemme. Yle Radio Suomen soittama musiikki jakautuu kaupallisia asemia tuntuvasti tasaisemmin eri kategorioihin, ja sen suhteellisen entropian indeksiluvut viittaavat erittäin suureen monipuolisuuteen, kun taas kaupallisten asemien indeksiluvut olivat vuonna 2017 enää keskimääräisiä ja selvästi laskeneet vuodesta 2013. Tulos tarkoittaa sitä, että siinä kun Radio Suomi tavoittelee monipuolisella eri aikakausien musiikin käytöllä hyvin erilaisia yleisöjä, Radio Nova ja Radio Suomipop keskittyvät vain tietyn ikäiseen musiikkiin ja siten myös tarkemmin rajattuun kohderyhmään.

Levy-yhtiöt. - Koska radioasemien soittama musiikki koostuu lähes yksinomaan levy-yhtiöiden julkaisuista, musiikkiteollisuuden valtarakenteet heijastuvat soitetun musiikin rakenteeseen. Oletimme kaupallisten asemien nojaavan Radio Suomea selvemmin suurten levy-yhtiöiden tuotantoon, minkä myös analyysi vahvistaa (taulukko 5). Radio Novan soittamasta musiikista lähes 90 prosenttia oli vuonna 2017 Big Three -yhtiöiden tuotantoa, ja osuus oli selvästi noussut sitten vuoden 2013. Myös Radio Suomipopin musiikkitarjontaa suuret levy-yhtiöt hallitsivat, mutta osuus oli selvästi pienempi kuin Novalla ja lisäksi laskusuunnassa, mikä viittaa siihen, että itsenäisillä levy-yhtiöillä on artisteja, jotka kiinnostavat Radio Suomipopin kuuntelijoita. Asemista vähiten Big Three yhtiöihin nojasi odotusten mukaisesti Radio Suomi, vaikka asema oli lisännyt niiden tuotantoa tarjonnassaan. Samat rakenteet toistuvat tarkasteltaessa erikseen radioasemien 
kotimaista musiikkia. Toisin kuin Suomipop, sekä Radio Nova että Radio Suomi olivat lisänneet Big Three -yhtiöiden musiikin saamaa soittoaikaa, jos kohta jälkimmäisen soittamasta kotimaisesta musiikista yhä runsaat 28 prosenttia oli indie-yhtiöiden tuotantoa, selvästi enemmän kuin kaupallisilla kilpailijoillaan.

\begin{tabular}{|c|c|c|c|c|c|c|}
\hline \multirow[b]{2}{*}{ Levy-yhtiöitä koskevat mittarit } & \multicolumn{2}{|c|}{ Yle Radio Suomi } & \multicolumn{2}{|c|}{ Radio Nova } & \multicolumn{2}{|c|}{ Radio Suomipop } \\
\hline & 2013 & 2017 & 2013 & 2017 & 2013 & 2017 \\
\hline Big Three -yhtiöiden osuus soitoista (\%) & 64,6 & 73,7 & 80,6 & 89,5 & 88,7 & 82,0 \\
\hline Big Three -yhtiöiden osuus kotimaisista soitoista (\%) & 60,3 & 71,6 & 70,3 & 87,3 & 88,7 & 82,0 \\
\hline
\end{tabular}

Taulukko 5. Big Three -levy-yhtiöiden asema soittolistoilla

\section{Kolmen radioaseman musiikkiprofiilit}

Yle Radio Suomi. - Radio Suomi on selvä markkinajohtaja päivittäin tavoittamansa yleisömäärän vuoksi. Asema on vahvimmillaan yli 45-vuotiaiden kuuntelijoiden keskuudessa, kun taas alle 45-vuotiaiden suosiossa se häviää Novalle ja Suomipopille (Finnpanel 2018). Toisin kuin kilpailijansa Radio Suomi ei ole puhdas musiikkikanava, vaan myös Ylen pääuutiskanava, joka tarjoaa lisäksi ajankohtaisohjelmia ja myös alueohjelmaa, jota se lähettää 18 taajuudella eri puolilla Suomea.

Yle Radio Suomi erottuu kilpailijoistaan myös siksi, että itseään toistavan soittolistan sijasta sen musiikkiprofiiliin kuuluu erikseen toimitettuja musiikkiohjelmia, joita se lähettää viikoittain 27 tuntia. Jo näiden ohjelmien nimiä katsomalla syntyy mielikuva monipuolisuudesta: Bluesministeri Esa Kuloniemi, Entisten nuorten sävellahja, Hitit ojoon, Kadonneen levyn metsästäjät, Kantritohtori Teppo Nättilä, Levylautakunta, Pekka Laineen Ihmemaa, Rocktoimittajan illallinen, Sekahaku, Suomi soi, Susanna Vainiolan Popradio, Tarja Närhin Iskelmäradio... Paitsi että erikoisohjelmat eivät lainkaan perustu soittolista-ajatteluun, niiden tarjoama musiikki ei myöskään ole päivänpolttavan ajankohtaista, vaan kattaa laveasti populaarimusiikin eri aikakausia ja tyylejä ja muistuttaa, että soitettavaksi löytyy paljon mielenkiintoista populaarimusiikkia, joka ei sovi formaatin ahtaisiin raameihin. 
Erikoisohjelmisto selittää myös Radio Suomen kaksijakoisen monipuolisuuden: Toisaalta kanava lähettää paljon 200o-luvun musiikkia (46,8 \%) mutta paljon myös musiikkia vuosilta ennen 1980-lukua. Prime timen ohjelmistossa kategoriat A, B ja C kuitenkin korostuvat (53,3\%), kun taas kategorian F painoarvo vähenee. Radio Suomen musiikkiprofiilin viimeaikainen arvostelu saattaakin liittyä siihen, että asema on nuorentanut nimenomaan parhaan kuunteluajan alueohjelmien yhteydessä soittamaansa musiikkia samalla, kun perinteinen iskelmä on rajattu erikoisohjelmiin. Toisaalta parhaana kuunteluaikana myös kotimainen musiikki on hieman enemmän esillä kuin illan ja yön tarjonnassa.

Tarkasteltaessa viikon 36 eniten soitettuja esityksiä vuonna 2017 käy ilmi, että Radio Suomen soittolistan kärkeen pääsee, kun esitystä toistetaan viikon aikana seitsemän kertaa, eli kerran päivässä (taulukko 6). Esitysten toisto on maltillista, koska kaupallisella asemalla voimasoitossa oleva esitys saattaa soida prime timessa kolmen tunnin välein (Hellman \& Vilkko 2016; Uimonen 2011). Listaa hallitsevat uudet kotimaiset julkaisut, joista kuusi on Warnerin tuotantoa. Universal on päässyt listalle yhdellä artistilla. Myös indie-yhtiöiden edustus kärkikymmenikössä on vahva.

$\begin{array}{lllll}\text { Esitys } & \text { Artisti } & \text { Levy-yhtiö } & \text { Ilmestymisvuosi } & \text { Soittokertoja } \\ \text { 1. Sinuna olisin hiljaa } & \text { Ufo Mustonen } & \text { Impossible Music } & 2017 & 7 \\ \text { 1. Taivas ei oo rajana } & \text { Mikko Harju } & \text { Warner } & 2017 & 7 \\ \text { 1. Etten ihan turhaan elänyt } & \text { Suvi Teräsniska } & \text { Warner } & 2016 & 7 \\ \text { 4. Kyl sä tiiät } & \text { Stina Gris } & \text { Kaiku } & 2017 & 6 \\ \text { 4. Disko } & \text { Tero Vesterinen } & \text { Lee van Cleff \& Lasso } & 2017 & 6 \\ \text { 4. Syliin } & \text { Vilma Alina } & \text { Warner } & 2017 & 6 \\ \text { 4. Se oikea } & \text { Jenni Vartiainen } & \text { Warner } & 2017 & 4 \\ \text { 8. Itsenäisyyspäivä } & \text { Antti Pouta } & \text { M.Dulor } & 2016 & 4 \\ \text { 8. Me tehtiin tää } & \text { Robin } & \text { Universal } & 2017 \\ \text { 8. Aamukuuteen } & \text { Antti Tuisku } & \text { Warner } & 2017 & 4 \\ \text { 8. Muitaki ihmisii } & \text { Vesala } & \text { Warner } & 2017 \\ \text { 8. Versace on the Floor } & \text { Bruno Mars } & \text { Warner } & 2016 & 4\end{array}$

Taulukko 6. Yle Radio Suomen eniten soittamat esitykset viikolla 36 vuonna 2017 
Yle Radio Suomi on aloittanut vuonna 2017 musiikkistrategiansa kehitystyön (Yle 2018), mikä näkyy monipuolisuutta lisäävinä muutoksina vuoteen 2013 verrattuna. Muutokset ovat vieneet Radio Suomen musiikkitarjontaa entistä kauemmas toistoon nojaavasta soittolista-ajattelusta. Tästä kertoo myös musiikin suuri vaihtuvuus: syyskuun viikolla 36 vuonna 2017 soitetuista 1274 esityksestä vain $76(5,9 \%)$ oli soinut myös saman vuoden maaliskuun viikolla 1o. Syksyllä 2017 kuulluista esityksistä vain 43 (3,4 \%) oli kuulunut aseman ohjelmistoon keväällä 2013.

Radio Nova. - Toimiluvan mukaan Radio Novan "musiikkisisällön tulee koostua laajalle kuuntelijajoukolle suunnatusta populäärimusiikista" (Viestintävirasto 2016). Aseman mediakortin mukaan Radio Novan taajuudella soi "paras sekoitus uutta musiikkia ja tunnettuja klassikoita aina 8o-luvulta tähän päivään" (Radiomedia 2018a). Käytännössä aseman formaatti nojaa ulkomaiseen musiikkiin ja nostalgiaan. Kotimaisten julkaisujen osuus soitoista on vähentynyt merkittävästi vuodesta 2013 samalla, kun 200o-luvun musiikin (kategoriat A, B, C) osuus on laskenut kolmesta neljänneksestä vuonna 2013 runsaaseen kolmannekseen vuonna 2017. Yli puolet (56,7\%) aseman musiikista on peräisin 1980- ja 1990-luvulta (kategoriat D ja E). Strategian onnistumiseen viittaa se, että Nova on parin viime vuoden aikana onnistunut lisäämään tavoittavuuttaan ikäryhmässä 25-44 (Finnpanel 2018; Tilastokeskus 2018). Nostalgian ja ulkomaisen musiikin painotukset erottavat Novan selvästi sekä Suomipopista että Radio Suomesta.

Kotimaiset esitykset ja artistit korostuvat jonkin verran Novan prime timessa sekä nousevat esiin myös soitetuimpien esitysten listalla. Soitetuin vuoden 2017 syksyn tutkimusviikolla oli Tuure Kilpeläisen Surusilmäinen kauneus, joka kuultiin 25 kertaa (taulukko 7), eli enemmän kuin kolmesti päivässä. Vaikka puolet listasta koostuu ulkomaisista artisteista, kotimaista mielikuvaa vahvistavat Mikael Gabriel, Juha Tapio, Poju ja Vesala. Näyttää siltä, että soittolistan kärjessä olevat suomalaisartistit muodostavat Novan kotimaisuusasteen ytimen, sillä heidän osuutensa toistoineen on kolmannes kanavan kotimaisen musiikin soitoista. Soittolistan kärjessä on vain kolme esitystä vuodelta 2017. Nova suosii selvästi Big Three -yhtiöitä, sillä kärkikymmenikköön mahtui vain yksi indie-levytys, joka sekin oli vakiintuneen valtavirta-artistin Juha Tapion tuotantoa. 


$\begin{array}{lllll}\text { Esitys } & \text { Artisti } & \text { Levy-yhtiö } & \text { Ilmestymisvuosi } & \text { Soittokertoja } \\ \text { 1. Surusilmäinen kauneus } & \text { Tuure Kilpeläinen } & \text { Universal } & 2016 & 25 \\ \text { 2. Skin } & \text { Rag'n'bone Man } & \text { Sony } & 2016 & 24 \\ \text { 2. Mixed Signals } & \text { Robbie Williams } & \text { Sony } & 2016 & 24 \\ \text { 4. Riippumatto } & \text { Mikael Gabriel } & \text { Universal } & 2017 & 22 \\ \text { 5. Despacito } & \text { Luis Fonsi } & \text { Universal } & 2012 & 21 \\ \text { 6. Älä lähde vielä pois } & \text { Juha Tapio } & \text { Kaiku } & 2015 & 17 \\ \text { 7. There's Nothing Holding Me Back } & \text { Shawn Mendes } & \text { Universal } & 2016 & 15 \\ \text { 7. Poika polkee } & \text { Poju } & \text { Warner } & 2011 & 15 \\ \text { 7. Muitaki ihmisii } & \text { Vesala } & \text { Warner } & 2017 & 15 \\ \text { 7. Sign of the Times } & \text { Harry Styles } & \text { Sony } & 2017 & 15\end{array}$

Taulukko 7. Radio Novan eniten soittamat esitykset viikolla 36 vuonna 2017

Uudistaessaan ilmettään talvella 2015 Radio Nova lisäsi juontajien ja vähensi soittolistan merkitystä (Radio Nova 2015). Yleisön mielipide kilpailutilanteessa näyttää ohjanneen kanavan musiikkiprofiilia myös muuttumattomuuteen. Syksyllä 2017 kanavan soittolistalla oli vielä 151 samaa esitystä (22 \%) kuin keväällä 2013 ja syyskuussa 2017 edelleen 548 samaa teosta (88 \%) kuin saman vuoden maaliskuussa.

Radio Suomipop. - Toimiluvan perusteella Radio Suomipopin lähettämän ohjelmiston "musiikkisisällön tulee koostua pääosin suomalaisesta populaari- ja viihdemusiikista", eli jo toimilupa rajaa sen musiikin kotimaiseksi (Viestintävirasto 2011). Mediakortissaan kanava markkinoi itseään kotimaisen musiikin ja popkulttuurin moniottelijana: "Se soittaa isoimmat klassikot ja tämän päivän superhitit" (Radiomedia 2018b). Suomipopin musiikillinen fokus on kuitenkin selvästi uudessa musiikissa, sillä lähes 90 prosenttia sen toistamasta musiikista on julkaistu 2000-luvulla, mikä erottaa sen todella selvästi Radio Suomesta ja Novasta. Suomipopin tarjontaa ei formaatin sisällä kuitenkaan voi pitää kovin monipuolisena, sillä soittolista toistaa itseään voimakkaasti. Vuoteen 2013 verrattuna musiikin soittojen määrä on lisääntynyt, mutta samalla entistä pienempi määrä esityksiä soi entistä useammin. 
Syksyn tutkimusviikolla 2017 kanavan kymmenen soitetuimman esityksen joukossa on seitsemän saman vuoden julkaisua, joten Radio Suomipop näyttää olevan pääkohderyhmänsä mukaisesti nuorille aikuisille suunnattu uuden kotimaisen hittimusiikin kanava (taulukko 8). Huomionarvoista on, että Nelonen Mediaan kuuluvan Suomipopin soittolistan kärkikymmenikössä on kuusi Warner Musicin julkaisemaa esitystä. Warner on mukana myös tv-kanava Nelosen suositussa Vain elämää -sarjassa, jonne musiikin valitsee sama musiikkipäällikkö kuin yhtiön kaikille radiokanaville, Mikko Koivusipilä (Mattila 2017; Räisänen 2017). Radio Suomipopin kymmenen soitetuimman artistin joukossa oli neljä saman syksyn Vain elämää -artistia: Kaija Koo, Juha Tapio, Jenni Vartiainen ja Sanni. Kolme muuta listan artistia - Robin, Samu Haber ja Olli Lindholm - olivat mukana edellisellä tuotantokaudella. Samu Haberin esittämä Hiljaisuus on päässyt soittolistan kärkeen 83 toistolla, mikä tarkoittaa, että esitys on soinut viikon aikana yli kymmenen kertaa päivässä.

$\begin{array}{lllll}\text { Esitys } & \text { Artisti } & \text { Levy-yhtiö } & \text { Ilmestymisvuosi } & \text { Soittokertoja } \\ \text { 1. Hiljaisuus } & \text { Samu Haber } & \text { Warner } & 2017 & 83 \\ \text { 2. Tuhoutuva tarina } & \text { Olli Lindholm } & \text { Warner } & 2017 & 80 \\ \text { 3. Nää yöt ei anna armoo } & \text { Kaija Koo } & \text { Warner } & 2016 & 72 \\ \text { 4. Sitä saat mitä tilaat } & \text { JVG } & \text { PME Records } & 2017 & 68 \\ \text { 5. Me tehtiin tää } & \text { Robin } & \text { Universal } & 2017 & 46 \\ \text { 6. Trampoliini } & \text { Sanni } & \text { Warner } & 2016 & 45 \\ \text { 6. Se oikea } & \text { Jenni Vartiainen } & \text { Warner } & 2017 & 45 \\ \text { 8. Aamukuuteen } & \text { Antti Tuisku } & \text { Sony } & 2017 & 44 \\ \text { 9. Muitaki ihmisii } & \text { Vesala } & \text { Warner } & 2017 & 42 \\ \text { 10. Älä lähde vielä pois } & \text { Juha Tapio } & \text { Kaiku } & 2015 & 40\end{array}$

Taulukko 8. Radio Suomipopin eniten soittamat esitykset viikolla 36 vuonna 2017

Tässä on kyse Suomipopin ja Nelosen välisestä markkinointiyhteistyöstä, joka yhdistettynä samaan konserniin kuuluvan Ilta-Sanomien tarjoamaan palstatilaan mahdollistaa poikkeuksellisen laajan medianäkyvyyden Warnerin artisteille ja musiikille. Tämä konsernisynergia kertoo paitsi ristiinmarkkinoinnista 
myös musiikkia ja artisteja koskevan julkisuuden televisioitumisesta (Herkman 2005), jossa radiolla on kuitenkin oma roolinsa. Musiikkipäällikkö Koivusipilän sanoin: "Kun tehdään supertähtiä, niin ensin on biisi, radion kautta siihen saadaan tarina, ja sitten kun lähdetään tekemään tosi isoa, tarvitaan vielä kasvot ja otetaan tv mukaan" (Mattila 2017). Tämä yhteistyö vahvistaa tähtikulttia, mitä voidaan jälleen käyttää hyödyksi iltapäivälehdissä ja erilaisissa tv-ohjelmissa niiden omistajien eduksi.

Pelkästään musiikin määrän perusteella Suomipop keskittyy nimenomaan musiikkiin, vaikka mukaan mahtuu myös puhetta, joka mediakortin lupauksen mukaan paneutuu "suomalaisia kiinnostaviin aiheisiin tv-ohjelmista julkkiksiin tai elokuvista ruokavillityksiin" (Radiomedia 2018b). Suomipopin soittolistan pitkän aikavälin muuttumattomuus on silmiinpistävän suurta: syksyllä 2017 sen kapealla soittolistalla oli edelleen 105 samaa esitystä (39\%) kuin keväällä 2013 ja peräti 152 samaa esitystä ( $57 \%$ ) kuin saman vuoden maaliskuussa.

\section{Yhteinen formaatti ei tarkoita päällekkäisyyttä}

Tutkimuksen pääväite oli, että koska kilpailu radiotoimialalla on varsin maltillista, samaa musiikkiformaattia edustavat asemat pyrkivät tuotedifferentiaation keinoin pikemminkin erottumaan toisistaan kuin matkimaan toisiaan. Vertailun kohteeksi valitut Yle Radio Suomi, Radio Nova ja Radio Suomipop ovat maan kolme kuunnelluinta radioasemaa ja musiikkiformaatiltaan kaikki ACasemia. Niiden soittolistoja vertailtiin käyttämällä muuttujina soitetun musiikin monipuolisuutta, kotimaisuutta, ikää ja omistusta sekä kehittämällä näitä kuvaavia määrällisiä mittareita. Lisäksi olemme piirtäneet tulosten perusteella kunkin aseman musiikillisen profiilin. Tulokset osoittavat selvästi, että yhteisestä musiikkiformaatistaan huolimatta asemat eivät ole musiikkianniltaan toistensa duplikaatteja eivätkä musiikkinsa osalta näytä kilpailevan keskenään. Kaupallisten asemien Novan ja Suomipopin soittolistat ovat useimmilla mittareilla arvioituina kapeita, kun taas julkisen palvelun Radio Suomen musiikkitarjonta on monipuolisuudeltaan, aikakausien kirjoltaan sekä esitysten ja artistien määrällä mitattuna täysin omaa luokkaansa. Jo musiikkiannin perusteella Radio Suomea 
voidaan pitää täyden palvelun AC-asemana, kun taas Nova ja Suomipop ovat kapean musiikkitarjonnan mainstream-asemia (Barnes 1988).

Yle Radio Suomi ei testaa lähettämänsä musiikin suosiota, ja lisäksi asemalla on poikkeuksellisen suuri määrä musiikin erikoisohjelmia omine toimittajineen, joiden musiikkivalintoja ohjataan vain yleisellä tasolla. Toisin kuin Nova ja Suomipop, jotka soittavat ainoastaan kuulijakuntansa hyväksymää rajattua määrää suosittuja teoksia, Radio Suomen tarjonta ei näytä nojaavan sen enempää hittiajatteluun kuin tähtikulttiinkaan. Toisaalta myös Nova ja Suomipop eroavat toisistaan paitsi soittolistan laajuuden ja kotimaisuusasteen osalta myös siinä, miten ne käyttävät aikakausia soittolistansa rakennuspuina. Näistä syistä soittolistojen päällekkäisyys teostasolla on hyvin vähäistä. Syksyn 2017 tutkimusviikolla tutkituilla kanavilla oli ainoastaan 11 yhteistä esitystä, kaikki kotimaisia. Radio Suomella oli Suomipopin kanssa 43 yhteistä esitystä, Novan kanssa taas 54, jälkimmäiset pääosin 1980-90-lukujen ulkomaisia hittejä. Radio Suomipopin ja Radio Novan vähäistä yhteistä kosketuspintaa kuvaa se, että niillä oli tutkimusviikolla soitossa ainoastaan 39 yhteistä (kotimaista) teosta.

Vaikka soittolistojen kotimaisuusaste vaihtelee, soitetuimpien (Top 10) esitysten tarkastelu osoitti, että kaikki asemat panostavat uuteen kotimaiseen musiikkiin. Tämä johtuu Ac-formaatista, joka yleisimmillään tarkoittaa populaarimusiikin valtavirtaa ja nimenomaan nuorille aikuisille suunnattua, helposti lähestyttävää ja pehmeitä sävyjä suosivaa tyyliä. Sitä voisi luonnehtia popiskelmäksi. Jalkanen ja Kurkela (2003: 617) ovat katsoneet radioaaltojen "rokittuneen" kaupallisen radion myötä, mutta nykyisten Ac-asemien musiikin voisi pikemminkin nähdä "popittuneen" ja popiskelmästä tulleen radioaaltojen valtavirtaa. Se mikä oli ennen rockia tai poppia, koetaan nykyään usein iskelmäksi: Eppu Normaali, Lauri Tähkä, Hector ja Popeda ovat iskelmätähtiä siinä missä Katri Helena, Jari Sillanpää, Kaija Koo ja Paula Koivuniemi. Hyviä esimerkkejä erilaisia musiikkigenrejä keskenään sekoittavista artisteista ovat vaikkapa Jenni Vartiainen, Haloo Helsinki, Chisu, Robin, Jonna Tervomaa ja Jukka Poika, joiden musiikissa rockin saundit ja esimerkiksi elektronisen tanssimusiikin tai reggaen rytmit usein yhdistyvät popin pehmeään laulullisuuteen.

Kaikki kanavat tavoittelevat menestyneiden artistien avulla nuorekasta yleisöä, koska ne pelkäävät, että kohdeyleisön vanheneminen ajaa kanavan pitkällä aikavälillä paitsioon. Yleispopulaarimusiikiksi liudentuneen kotimaisen pop- 
iskelmän ja ulkomaisen popin valtiaita ovat kolme suurta levy-yhtiötä, joiden yhteenlaskettu osuus kolmen kuunnelluimman radioaseman soitoista on yli 80 prosenttia, Radio Suomellakin vain marginaalisesti sitä pienempi. Erityisen vahva rooli on Warnerilla, joka on uuden kotimaisen hittimusiikin johtava tuottaja. Tutkitut radioasemat vahvistavat omilla soittolistoillaan suurten levy-yhtiöiden valtaa musiikkimarkkinoilla.

Olemme myös osoittaneet, että Radio Suomen, Radio Suomipopin ja Radio Novan soittolistat ovat erilaisia, koska ne tavoittelevat osin erilaista yleisöä. Radioyleisö rakennetaan paljolti soittamalla musiikkia, jota kohderyhmän joko uskotaan tai tiedetään haluavan. Tutkimuksen kaupalliset toimijat ovat erityisen kiinnostuneita nuorista aikuisista, ikäryhmästä 25-44. Radio Suomipop tavoittaa tämän ikäryhmän soittamalla 200o-luvun musiikkia, ja myös Radio Nova on soittolistansa musiikin ikää säätämällä onnistunut kasvattamaan ryhmän osuutta kuulijakunnassaan. Vaikka Radio Suomenkin prime time on muuttunut aiempaa nuorekkaammaksi, sen laaja valikoima väistelee hittejä ja nojaa muita selvemmin suurten ikäluokkien nuoruuden musiikkiin, minkä vuoksi se ei pärjää kilpailussa ikäryhmästä 25-44.

Tutkimus tähdentää myös sitä, kuinka radiokilpailussa menestyminen näyttää vaativan monipuolisia resursseja. Radio Suomen takana on Yleisradion brändi sekä mahdollisuus ohjelmien markkinointiin omilla tv-kanavilla. Radio Nova on edelleen läheisessä yhteistyössä entisen omistajana MTv:n kanssa. Nelonen Median monipuolinen media-arsenaali osana Sanoma-konsernia tukee selvästi Radio Suomipopin menestystä, sillä sen soittolistat näyttävät nykyisin korreloivan myös muun mediajulkisuuden kanssa. Vain elämää, The Voice of Finland ja Idols tuottavat artisteille tärkeää tv-näkyvyyttä, joka tasoittaa näiden julkkisten tietä soittolistoille. Vallitsevan markkinointikäsityksen mukaan menestyminen kilpailutilanteessa vaatii näkyvyyttä monessa eri mediassa. Tämä pitää paikkansa myös radiokanavien välisessä kilpailussa.

Tulosten tilastollista merkitsevyyttä ei tässä ole katsottu mielekkääksi testata, sillä muutokset ja etenkin asemien väliset erot ovat selviä. Soittolistojen vakiintuneesta rakenteesta ja hitaasta muuttumisesta johtuen otosviikkoja koskevat tulokset kuvaavat hyvin täsmällisesti radion musiikkitarjonan rakenteita. Tutkimus vahvistaa myös käytettyjen määrällisten mittarien hyödyllisyyden. Musiikin tarkastelu neljällä eri ulottuvuudella antaa asemien soittolistoista monipuolisen 
kokonaiskuvan, jossa eri mittarit täydentävät toisiaan. Esimerkiksi soittolistalla olevien esitysten määrä antaa vain yhden viestin soittolistan laajuudesta; tieto tarkentuu merkittävästi, kun mitataan myös listalla olevien artistien määrää, esitysten keskimääräistä toistojen määrää ja vain kerran viikossa kuultujen esitysten osuutta. Tulevissa tutkimuksissa on tarpeen kehitellä soittolistojen päällekkäisyyttä kuvaavia mittareita (Williams ym. 2002), jollaisia on käytetty esimerkiksi television ohjelmarakenteen tutkimuksessa (Hellman 2001). Samoin on syytä vertailla systemaattisemmin parhaan kuunteluajan musiikkitarjontaa ilta- ja yöajan soittolistaan. Aineisto antoi viitteitä siitä, että prime time -tunteina sekä kotimainen että uudempi musiikki korostuvat. Vaikka radiosoittoja ei tässä analysoitu musiikkityylien näkökulmasta, ei genreä voida hylätä asemien potentiaalisena erottumisen ulottuvuutena. Tuleva tutkimus voisi paneutua genreen aidosti kuuntelemalla radioasemia ja vertailemalla niitä tuntuvasti pienemmän aineiston avulla.

Tutkimus on osoittanut, että vallitsevan maltillisen kilpailun oloissa samaa formaattia edustavat suositut kanavat pyrkivät erottumaan toisistaan. Kuinka maltillisena kilpailu radiotoimialalla säilyy, riippuu mediapolitiikan suunnasta. Valtioneuvosto myöntää vielä ennen vuodenvaihdetta radioasemien toimiluvat vuosiksi 2020-2029. Liikenne- ja viestintäministeriön tavoitteena on menettelyn keventäminen, jolloin toimilupia myönnettäessä päähuomio kiinnittyisi hakijan edellytyksiin harjoittaa pitkäjänteistä radiotoimintaa. Samalla ohjelmatoiminnan sisältöön liittyvistä ehdoista luovutaan, koska ne aiheuttavat "jäykkyyttä reagoida muuttuvaan markkinatilanteeseen tai kuuntelijakunnan toiveisiin" (Liikenneja viestintäministeriö 2018, 5). Kun musiikkisisältöä koskevat toimilupaehdot nyt aiotaan sivuuttaa, kilpailun radioasemien kesken voidaan olettaa lisääntyvän, mikä väistämättä heijastuu myös niiden formaattivalintoihin ja soittolistoihin. Kiristyvä kilpailu ei ole omiaan lisäämään radion tarjoaman musiikin monipuolisuutta.

\section{Kirjallisuus}

Ahlkvist, Jarl A. \& Fisher, Gene (2000) "And the hits just keep on coming: Music programming standardization in commercial radio." Poetics, 27(5-6), 301-325. 
Ala-Fossi, Marko (1999) Tähden kylmä loiste: Radio Novan markkinoilletulon vaikutus Suomen kaupallisten paikallisradioiden toimintaan. Tiedotusopin laitoksen julkaisuja A92. Tampere: Tampereen yliopisto.

Ala-Fossi, Marko (2005) Saleable Compromises: Quality Cultures in Finnish and US Commercial Radio. Tampere: Tampere University Press.

Ala-Fossi, Marko (2006a) "Yhä enemmän sitä samaa: Miksi kaupalliset radiokanavat samankaltaistuvat?" Tiedotustutkimus, 29(1), 126-137.

Ala-Fossi, Marko (2006b) Toimiluvanvarainen radiotarjonta 2006: Yksityisten analogisten radiokanavien sisältötarjonta 20 suomalaiskaupungissa. Liikenne- ja viestintäministeriön julkaisuja 4/2006. Helsinki: LVM.

Ala-Fossi, Marko (2008) "Aina äänessä, mutta vastahakoisesti valokeilassa? Kaupallisen radion tutkimuksen esteitä ja erityispiirteitä." Radio- ja televisiotutkimuksen metodologiaa: Näkökulmia sähköisen viestinnän tutkimiseen. Toim. Heidi Keinonen, Marko Ala-Fossi \& Juha Herkman. Tampere: Tampere University Press, 33-47.

Ala-Fossi, Marko \& Haara, Paula (2010) Toimiluvanvarainen radiotarjonta 2009: Yksityisten analogisten radiokanavien sisältötarjonta 20 suomalaiskaupungissa. Liikenne- ja viestintäministeriön julkaisuja 4/2010. Helsinki: LVM.

Albarran, Alan B. (2002) Media Economics: Understanding Markets, Industries and Concepts. Ames: Iowa State University Press.

Barnard, Stephen (2000) Studying Radio. Lontoo: Arnold.

Barnes, Ken (1988) "Top 40 radio: A fragment of the imagination." Facing the Music. Toim. Simon Frith. New York: Pantheon Books, 8-50.

Berry, Steven T. \& Waldfogel, Joel (1999) "Public radio in the United States: Does it correct market failure or cannibalize commercial stations?" Journal of Public Economics, 71(2), 189211.

Bonini, Tiziano; Fesneau, Elvina; Perez, J. Ignacio Gallego; Luthje, Corinna; Jedrzejewski, Stanislaw; Pedroia, Albino; Rohn, Ulrike; Sellas, Toni; Starkey, Guy \& Stiernstedt, Fredrik (2014) "Radio formats and social media use: 28 case studies of public service practice." The Radio Journal: International Studies in Broadcast \& Audio Media, 12(1-2), 89-107.

Chambers, Todd (2003) "Radio programming diversity in the era of consolidation." Journal of Radio Studies, $10(1), 33-45$.

Dimmick, John \& McDonald, Daniel G. (2001) "Network radio oligopoly, 1926-1956: Rivalrous imitation and program diversity." Journal of Media Economics, 14(4), 197-212. 
Dowd, Timothy J. (2004) "Concentration and diversity revisited: Production logics and the U.S. mainstream recording market, 1940-1990." Social Forces, 82(4): 1411-1455.

Finnpanel (2018) "Radionkuuntelu Suomessa 2017." https:/ / www.finnpanel.fi/lataukset/ radiovuosi_2017.pdf (luettu 15.2.2018).

Gronow, Pekka \& Kaitajärvi-Tiekso, Juho (2017) "Äänitallenteet." Suomen mediamaisema. Toim. Kaarle Nordenstreng \& Hannu Nieminen. Tampere: Vastapaino, 253-281.

Hagen, Anja Nylund (2015) "The playlist experience: Personal playlists in music streaming services. Popular Music and Society, 38(5): 625-645.

Hellman, Heikki (2001) "Diversity - an end in itself? Developing a multi-measure methodology of television programme variety studies." European Journal of Communication, 16(2), 181-208.

Hellman, Heikki \& Vilkko, Arto (2016) "Julkisen palvelun hittiradio? Soittolista erottautumiskeinona kilpailussa kuuntelijoista." Media \& viestintä, 39(2), 73-92.

Hendy, David (2000) "Pop music radio in the public service: ввс Radio 1 and new music in the 1990s." Media, Culture \& Society, 22(6), 743-762.

Herkman, Juha (2005) Kaupallisen television ja iltapäivälehtien avoliitto: Median markkinoituminen ja televisioituminen. Tampere: Vastapaino.

Hujanen, Taisto \& Ala-Fossi, Marko (2017) "Radio." Suomen mediamaisema. Toim. Kaarle Nordenstreng \& Hannu Nieminen. Tampere: Vastapaino, 138-164.

Iltalehti (18.10.2017) "Kyösti Mäkimattila tulistui - kritisoi Ylen radioiden musiikkitarjontaa: 'Varttuneempaa kuulijakuntaa lyödään korville'." http:/ /www.iltalehti.fi/ viihdeuutiset/201710182200470077_vd.shtml (luettu 20.1.2018)

Jalkanen, Pekka \& Kurkela, Vesa (2003) Suomen musiikin historia: Populaarimusiikki. Helsinki: wSOY.

Kemppainen, Pentti (2009) "Reporadiosta rockradioon." Musiikki tekee murron: Tutkimuksia sävelja hittiradioista. Toim. Vesa Kurkela. Musiikintutkimuksen laitoksen julkaisuja 2. Tampere: Tampereen yliopisto, 85-142.

Kemppainen, Pentti (2015) Radio kuuluu kaikille: Kaupallisen radion historia Suomessa. Helsinki: Radiomedia ja Into Kustannus.

Kontukoski, Maija (2012) Paikallisradiosta musiikkiradioon: Tapaustutkimus eteläpohjalaisen Radio Paitapiiskan toimintakulttuurin ja musiikinvalintaprosessin muutoksista vuosina 1985-2006. Acta Universitatis Tamperensis 1711. Tampere: Tampere University Press.

Kostamovaara, Merja (2012) Iskelmä muuttuu muuttumatta: Suomalaisen iskelmän rakentuminen Iskelmä Finlandia -palkinnosta julkaistuissa lehtiartikkeleissa. Musiikintutkimuksen pro gradu, Tampereen yliopisto. 
Krämer, Benjamin (2009) "Four voices, one canon? A comparative study on the music selection of classical music radio stations." European Journal of Communication, 24(3), 325-343.

Kurkela, Vesa (toim.) (2009) Musiikki tekee murron: Tutkimuksia sävel- ja hittiradioista. Musiikintutkimuksen laitoksen julkaisuja 2. Tampere: Tampereen yliopisto.

Kurkela, Vesa \& Uimonen, Heikki (2007). "Usko, toivo ja petollinen rakkaus: Rock-kulttuuri ja suomalaisen radiopolitiikan muutos." Etnomusikologian vuosikirja 2007. Toim. Heikki Uimonen \& Markus Mantere. Helsinki: Suomen Etnomusikologinen Seura, 3-27.

Liikenne- ja viestintäministeriö (2018) "Radion tuleva toimilupakausi." Muistio 14.5.2018. https: / / www.lvm.fi/lvm-site62-mahti-portlet/download?did=269267 (luettu 2.9.2018).

Litman, Barry R. (1992) "Economic aspects of program quality: The case for diversity." Studies of Broadcasting, (28), 121-156.

MacFarland, David T. (1997) Future Radio Programming Strategies: Cultivating Listenership in the Digital Age. Lontoo: Lawrence Erlbaum Associates.

Mattila, Ilkka (2017) "Radio tekee hitin." Helsingin Sanomat 27.5.2017, C1-C3.

McDonald, Daniel G. \& Dimmick, John (2003) "The conceptualization and measurement of diversity." Communication Research, 30(1), 60-79.

midiA (2017) "Global Recorded Market Music Market Shares 2016". Music Industry Blog. https:/ / musicindustryblog.wordpress.com/2017/02/26/global-recorded-market-musicmarket-shares-2016/ (luettu 30.3.2018).

Napoli, Philip M. (1999) "Deconstructing the diversity principle." Journal of Communication, 49(4), 7-34.

Negus, Keith (1992) Producing Pop: Culture and Conflict in the Popular Music Industry. Lontoo: Edward Arnold.

Nevasalmi, Kaisu (2014) Radio Suomi soi: Musiikin valinta Suomen suosituimmalla radiokanavalla. Medianomin opinnäytetyö, Metropolia Ammattikorkeakoulu, Elokuvan ja television koulutusohjelma.

Oinaala, Sampsa (2015) "Tämä mies päättää, mikä radiossa soi: Radio Suomen musiikkipäällikkö Jorma Hietamäen kädenjälki kuuluu kanavan ohjelmissa." Helsingin Sanomat 16.5.2015, C32. Picard, Robert G. (1989) Media Economics: Concepts and Issues. Newbury Park: Sage.

Polinsky, Heather (2007) "The factors affecting radio format diversity after the Telecommunications Act of 1996: Ownership concentration, stations and audience." Journal of Radio Studies, 14(2), 122-143.

Porter, Michael E. (1980) Competitive Strategy: Techniques for Analyzing Industries and Competitors. New York: Free Press. 
Radio Nova (2015) "Radio Nova uudistaa konseptinsa ja ohjelmakarttansa 16.2. alkaen." https:/ / www.radionova.fi/uutiset/ajankohtaista/a-100092 (luettu 5.6.2018).

Radiomedia (2018a) "Radio Nova: Mediakortti." http:/ / www.radiomedia.fi/radiokanavat/ mediakortit/radio-nova (luettu 28.1.2018).

Radiomedia (2018b) "Radio Suomipop: Mediakortti." http:/ / www.radiomedia.fi/radiokanavat/ mediakortit/radio-suomipop (luettu 28.1.2018).

Rogers, Robert P. \& Woodbury, John R. (1996) "Market structure, program diversity, and radio audience size." Contemporary Economic Policy, 14(1), 81-91.

Rothenbuhler, Eric T. (1985) "Programming decision making in popular music radio." Communication Research, 12(2), 209-232.

Räisänen, Kari (2017) "Raha ratkaisee radiohitit." Helsingin Sanomat 21.8.2017, A28-29.

Sauri, Tuomo \& Picard, Robert G. (2017) "Mediatalous." Suomen mediamaisema. Toim. Kaarle Nordenstreng \& Hannu Nieminen. Tampere: Vastapaino, 36-63.

Seemer, Jonas; Halonen, Antti \& Fredén, Lasse (2016) Selvitys Suomen radiomarkkinoista. Liikenneja viestintäministeriön julkaisuja 3/2016. Helsinki: LVM.

Tahvanainen, Helena (2017) "Radio Suomen musiikkivalinnat raivostuttavat varttunutta väkeä." Karjalainen 13.10.2017. https:/ / www.karjalainen.fi/uutiset/uutis-alueet/kotimaa/ item/158558-naekoekulma-radio-suomen-musiikkivalinnat-raivostuttavat-varttunuttavaekeae (luettu 20.1.2018).

Tilastokeskus (2018) "Joukkoviestintätilaston taulukkopalvelu: Radio." http:/ / pxhopea2.stat.fi/ sahkoiset_julkaisut/joukkoviestintatilasto/html/suomooo3.htm (luettu 28.1.2018).

Uimonen, Heikki (2008) "Kun kuulen tangon hiljaisen: Radiomusiikin muutos ja tutkimuksen metodologiset haasteet." Radio- ja televisiotutkimuksen metodologiaa: Näkökulmia sähköisen viestinnän tutkimiseen. Toim. Heidi Keinonen, Marko Ala-Fossi \& Juha Herkman. Tampere: Tampere University Press, 48-63.

Uimonen, Heikki (2009) "Lännen malliin: Radio Sata ja 1990-luvun musiikkiradiouudistus." Kulttuurintutkimus, 26(1), 25-38.

Uimonen, Heikki (2011) Radiomusiikin rakennemuutos: Kaupallisten radioiden musiikki 1985-2005. Tampere: Tampere University Press.

Valtioneuvosto (2011) "Valtioneuvoston päätös toimiluvista radiotoiminnan harjoittamiseksi, Liite 2." 17.2.2011, Dnro: LVM/1468/07/2010.

van der Wurff, Richard \& van Cuilenburg, Jan (2001) "Impact of moderate and ruinous competition on diversity: The Dutch television market." Journal of Media Economics, 14(4), 213-229. 
Viestintävirasto (2011) "Toimilupa radiotoiminnan harjoittamiseen, Metroradio Finland Oy [Radio Suomipop]." 17.2.2011, Dnro: LvM/1468/07/2010. https:/ / www.viestintavirasto. fi/attachments/muutpaatokset/Radiotoimilupa_Metroradio_Finland_Oy_5.pdf (luettu 20.1.2018).

Viestintävirasto (2016) "Ohjelmistotoimilupa radiotoiminnan harjoittamiseen, $3 \mathrm{~N}$ Radiot Oy [Radio Nova]." 21.12.2016, Dnro: 34087/731/2016. https:/ /www.viestintavirasto.fi/ attachments/Ohjelmistotoimilupa_-_3N_Radiot.pdf (luettu 20.1.2018).

Vilkko, Arto (2010) Soittolistan symbolinen valta ja vallankäytön mekanismit: Tutkimus viiden radioaseman formaatista ja musiikkitarjonnasta. Tampere: Tampere University Press.

Williams, George; Brown, Keith \& Alexander, Peter (2002) Radio Market Structure and Music Diversity. Media Bureau Staff Research Paper 2002-9. Federal Communications Commission. https:/ /apps.fcc.gov/edocs_public/attachmatch/Doc-226838A18.pdf (luettu 15.2.2018).

Yle (2018) "Ylen toimintakertomus ja tilinpäätös 2017." https:/ /yle.fi/aihe/ artikkeli/2018/03/21/ylen-toimintakertomus-ja-tilinpaatos-2017 (luettu 5.6.2018).

\section{Kiitokset}

Kiitämme Yleisradiota, Radio Novaa ja Radio Suomipopia luvasta saada käyttää musiikkiraportteja aineistona sekä Gramexin tilityspäällikköä Kari Niemelää aineiston ajamisesta tutkimusta varten. Samoin kiitämme nimettömiä arvioijia artikkelia koskeneista hyödyllisistä parannusehdotuksista. 